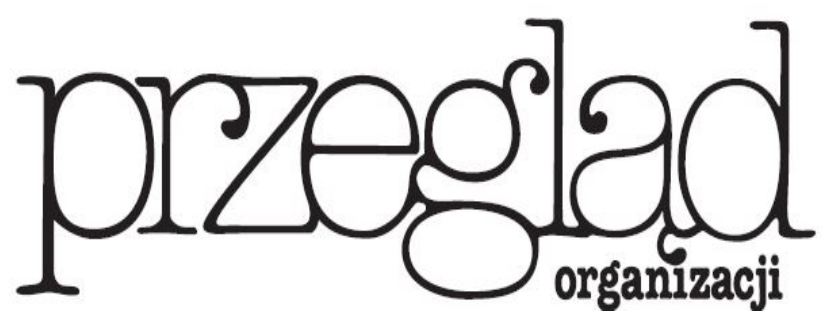

Miesięcznik TNOiK Założył Karol Adamiecki w 1926 r.

\title{
RODZINNOŚĆ POLSKICH PRZEDSIĘBIORSTW - STYMULATOR CZY PRZESZKODA INNOWACYJNOŚCI?
}

https://doi.org/10.33141/po.2019.07.04

Teresa Kraśnicka, Tomasz Ingram, Grzegorz Głód
Przegląd Organizacji, Nr 7 (954), 2019, ss. 22-31 www.przegladorganizacji.pl CTowarzystwo Naukowe Organizacji i Kierownictwa (TNOiK)

\section{Wprowadzenie}

$\mathbf{P}$

rzedsiębiorstwa rodzinne są dominującą formą prowadzenia działalności gospodarczej w większości krajów, przy czym szacuje się, że stanowią one od $60 \%$ do nawet $98 \%$ wszystkich przedsiębiorstw w różnych krajach (Daspit i in. 2017, s. 6). W Polsce ocenia się, że firmy rodzinne mogą stanowić nawet ponad $60 \%$ sektora małych i średnich przedsiębiorstw, ale dane na ten temat różnią się znacznie - w zależności od metodologii badań (Mączyńska, 2016, s. 95-96). Powszechnie docenia się pozytywny wpływ firm rodzinnych (dalej w tekście: FR) na rozwój gospodarki, wzrost zatrudnienia i dobrobyt (Jaskiewicz i in., 2017, s. 73; Jeżak, 2016). Szczególnie interesującym przedmiotem eks- ploracji jest czynnik rodzinności (familiness) i jego wpływ na różne aspekty funkcjonowania tych przedsiębiorstw, w tym ich innowacyjność czy wyniki (Naldi i in., 2013, s. 1341).

W badaniach FR stosuje się różne definicje (Kammerlander i in., 2015, s. 332; Naldi i in., 2013, s. 1341), w których wykorzystuje się łącznie lub niektóre $\mathrm{z}$ następujących kryteriów: czynny udział członków rodziny (1) we własności (2) w zarządzaniu oraz (3) łącznie - we własności i zarządzaniu (Duran i in., 2016, s. 1224). W nawiązaniu do stosowanych kryteriów wyodrębniania FR w badaniach przyjęto, że FR to podmioty gospodarcze charakteryzujące 
się dowolną wielkością (a także formą prawną), stanowiące w całości lub w decydującej części własność jednej osoby lub członków jednej rodziny i jednocześnie przez nich zarządzany (Steinerowska-Streb, 2015, s. 352).

Czynnik rodzinności, uznawany poznawczo za najbardziej interesujący w funkcjonowaniu FR (Daspit i in., 2017, s. 9), obejmuje wiązkę niematerialnych zasobów, które odzwierciedlają stopień zintegrowania rodziny, przedsiębiorstwa i zarządzania, stanowiąc tym samym istotny wyróżnik przedsiębiorstw rodzinnych, postrzegany jednocześnie jako źródło przewagi konkurencyjnej. Jednym $\mathrm{z}$ ważnych problemów badawczych jest określenie wpływu rodzinności na zakres innowacji FR, jako że innowacyjność może $\mathrm{w}$ istotny sposób determinować efektywność tych przedsiębiorstw, ich wzrost. W tym kontekście zwraca się uwagę na niektóre cechy przypisywane FR, takie jak nepotyzm czy konserwatyzm, które mogą nie sprzyjać rozwojowi FR. Natomiast inwestowanie $\mathrm{w}$ innowacje zwykle wiąże się z określonym ryzykiem, które może być oceniane jako zagrożenie dla bezpieczeństwa rodziny. Dlatego też natężenie rodzinności w przedsiębiorstwie rodzinnym jest przedmiotem badań i dyskusji czy wręcz kontrowersji (Dawson, Mussolino, 2014, s. 169; Zellweger i in., 2010, s. 54).

Badania naukowe dotyczące skutków zaangażowania rodziny w zarządzanie przedsiębiorstwem nie dają jednoznacznej odpowiedzi dotyczącej relacji: rodzinność - poziom innowacyjności; relacje te ocenia się jako złożone i trudne do pomiaru. $Z$ dotąd przeprowadzonych badań wynika, że zarówno zarządzanie innowacjami, jak i poziom innowacji w FR mogą się różnić od innych przedsiębiorstw, niebędących własnością i/lub pod kontrolą rodziny (Chrisman i in., 2015, s. 310). W literaturze prezentowane są wyniki badań dotyczące zarówno pozytywnych, jak i negatywnych relacji pomiędzy zaangażowaniem rodziny a nakładami na innowacje $\mathrm{w}$ przedsiębiorstwach rodzinnych (Diéguez-Soto i in., 2016, s. 327). Wyniki badań dotyczące innowacji w FR, nie są spójne i konieczne jest pogłębienie badań wpływu rodziny na procesy innowacyjne i zarządzanie nimi (Chrisman i in., 2015, s. 310; Kammerlander i in. 2015, s. 332). Ponadto należy podkreślić, iż w Polsce nieliczne są badania dotyczące czynnika rodzinności (Bratnicka-Myśliwiec, Ingram 2017; Kraśnicka i in., 2016), a także jego wpływu na innowacyjność przedsiębiorstw rodzinnych, funkcjonujących w warunkach posttransformacyjnych, z relatywnie krótką historią gospodarki rynkowej. Przesłanki powyższe uzasadniają prowadzenie badań w tym obszarze, których wyniki zaprezentowano w niniejszym artykule. Celem przeprowadzonych badań było zidentyfikowanie wpływu rodzinności na innowacje FR z założeniem moderującej roli wielkości przedsiębiorstw i ich wieku. Badania ilościowe przeprowadzono w 2017 r. na próbie 200 polskich FR.

\section{Rodzinność w literaturze przedmiotu}

W definiowaniu rodzinności i jej badaniach stosuje się różne podejścia, w których eksponuje się: zaangażowanie rodziny (Sharma i in., 2012), aspiracje i wpływ rodziny na firmę (Chrisman in., 2003) oraz organizacyjną tożsamość (Zellweger i in., 2010). Panuje dość powszech- ne przekonanie badaczy, że czynnik rodzinności jest koncepcją nader obiecującą, jeśli chodzi o rozpoznanie unikalności firm rodzinnych (Weismeier-Sammer i in., 2013, s. 166), stanowiąc ich zasadniczy wyróżnik (Chua $\mathrm{i}$ in., 2012). Termin „rodzinność” został prawdopodobnie wprowadzony przez T.G. Habbershona i M.L. Williams (1999), którzy odnoszą go do stopnia integracji pomiędzy rodziną, przedsiębiorstwem i zarządzaniem i traktują jako specyficzną dla danej firmy, unikalną wiązkę zasobów.

W wyjaśnianiu istoty rodzinności dominuje perspektywa zasobowa, czyli rozpatrywanie jej jako kombinacji zasobów społecznych, ludzkich, finansowych i fizycznych. Zmiany w poziomie rodzinności są konsekwencją przepływu pomiędzy tymi czterema formami kapitału (Sharma, 2008). Chociaż podejście zasobowe dostarcza często badaczom ram teoretycznych do badania rodzinności (Tokarczyk i in., 2007), to dostrzega się także jego słabości. To z kolei pociąga za sobą stosowanie równolegle różnorodnych perspektyw badawczych dla tego zjawiska, wśród których na szczególną uwagę zasługuje perspektywa kapitału społecznego, teorii systemów czy perspektywa teorii agencji (Weismeier-Sammer i in., 2013, s. 166).

Aby przezwyciężyć pewne słabości zasobowej teorii organizacji, w ostatnich latach pojawiła się propozycja wykorzystania założeń tzw. nowej teorii systemów - new system theory (NST), która jest pomocna w wyjaśnieniu wielowymiarowości i złożoności zjawiska rodzinności (Frank i in., 2016, s. 2). NST pozwala zintegrować dotychczas najczęściej stosowane podejścia do definiowania rodzinności. Podkreśla się, że teoria systemów może odegrać ważną rolę w badaniach przedsiębiorstw rodzinnych, gdyż pozwala lepiej zrozumieć złożoność funkcjonowania tych przedsiębiorstw, zredukować tę złożoność oraz przezwyciężyć istniejącą fragmentację badań (Von Schlippe, Frank, 2013, s. 384). NST zakłada, że podstawowymi elementami systemu społecznego są akty komunikowania się, a kluczowe znaczenie mają wzorce porozumiewania się, ich wzajemne związki, stanowiące przesłanki decyzji podejmowanych przez członków rodziny, dotyczących rodzinnego biznesu (Frank i in., 2016, s. 2-4). Powyższa koncepcja rodzinności i opracowane na jej podstawie narzędzie pomiaru (skala FIFS - Family Influence Familiness Scale) zostały wykorzystane w badaniach prezentowanych w niniejszym artykule.

\section{Związki rodzinności i innowacyjności FR w świetle badań literatury}

$\mathbf{Z}$ ainteresowanie badaczy problematyką innowacji wynika $\mathrm{z}$ istotnej roli, jaką odgrywają w rozwoju przedsiębiorstw, stanowiąc źródło ich przewagi konkurencyjnej (Poznańska, 2018; Fuetsch, Suess-Reyes, 2017). Współcześnie innowacje utożsamia się z: wytwarzaniem lub adaptowaniem, asymilacją i wykorzystaniem nowości dodających wartość zarówno w sferze ekonomicznej, jak i społecznej; modyfikacją i rozwojem produktów, usług, rynków; opracowaniem nowych metod produkcji, wprowadzeniem nowych systemów zarządzania (Crossan, Apaydin, 2010, s. 1155). W definiowaniu i wyodrębnianiu typów innowacji 
ważnych standardów dostarcza tzw. Oslo Manual (2005), stanowiący zbiór założeń metodologicznych dotyczących pomiaru innowacyjności przedsiębiorstw. Opracowanie to wyodrębnia innowacje technologiczne (produktowe i procesowe) i nietechnologiczne (organizacyjne i marketingowe). Jednocześnie warto zauważyć, że odrębnym przedmiotem badań są nie tylko dwie kategorie innowacji nietechnologicznych, ale także innowacje menedżerskie, zarządcze (management innovation), dotyczące procesu, struktur i metod zarządzania (Kraśnicka i in., 2016). Problematyka innowacyjności firm rodzinnych jest stale obecna w badaniach prowadzonych zarówno w Polsce (Kraśnicka, Głód, 2018), jak i na świecie (Arzubiagaa i in., 2018), a same badania innowacyjności FR charakteryzuje duża różnorodność podejmowanych problemów. Jeden $\mathrm{z}$ ważnych kierunków badań dotyczy różnych form wpływu rodziny na innowacyjnosśc przedsiębiorstw rodzinnych (Duran i in., 2016, s. 1224).

W wyniku badań dotyczących odpowiedzi na pytanie: jaki jest wpływ rodzinności na innowacje, choć nie są spójne, przeważa opinia, że jest ona ważnym czynnikiem kształtującym innowacyjność FR (Carnes, Ireland, 2013). Niektóre wyniki badań mówią o pozytywnym wpływie rodziny na innowacje (Llach, Nordqvist, 2010), a inne przeciwnie - o negatywnym, niekiedy $\mathrm{w}$ porównaniu $\mathrm{z}$ firmami nierodzinnymi (Muñoz-Bullón, Sanchez-Bueno, 2011). Takie niejednoznaczne wyniki pokazują różnorodność FR, ich różne cele i strategie innowacji (Classen i in., 2014, s. 595). Przedmiotem badań są w szczególności nakłady na innowacje $\mathrm{i}$ ich efekty $\mathrm{w}$ kontekście zaangażowania rodziny w zarządzanie firmą (Muñoz-Bullón, Sanchez-Bueno, 2011; Dieguez-Soto i in., 2016; Duran i in., 2016, s. 1224), a także wpływ własności, zarządzania i nadzoru właścicielskiego na wdrażanie innowacji przez FR (Matzler i in., 2015). Liczne są również porównania innowacyjności firm rodzinnych i nierodzinnych (Classen i in., 2014, s. 595), z których wynika, że firmy rodzinne są mniej innowacyjne (Steeger, Hoffmann, 2016). Z kolei badania J. Llacha i M. Nordqvista (2010) wskazują, że to firmy rodzinne są bardziej innowacyjne niż nierodzinne. Ponadto wyniki badań wskazują, że FR wdrażają mniej innowacji - w stosunku do posiadanych zdolności, potencjału - w porównaniu do przedsiębiorstw nierodzinnych, chociaż nie wszystkie wyniki badań są tu w pełni zgodne (De Massis i in., 2015).

Badania wpływu rodziny na innowacyjność FR uwzględniają podejście nakładowe (innovation input) oraz podejście wynikowe - innovation output (Duran i in., 2016, s. 1224; Diéguez-Soto i in., 2016), co pozwala na bardziej pogłębiony wgląd w procesy innowacyjne i ich uwarunkowania. Badania wskazują na dużą złożoność relacji pomiędzy firmą rodzinną a wdrażanymi w niej innowacjami. Znajduje to odzwierciedlenie $\mathrm{w}$ wynikach badań, m.in. potwierdzających negatywne relacje pomiędzy wymiarami rodzinności a nakładami na innowacje oraz jednocześnie pozytywne związki pomiędzy rodzinnością a wynikami wdrożonych innowacji (Duran i in., 2016, s. 1224). Podobnie badania K. Matzlera i innych (2015) potwierdzają negatywny wpływ zarządzania i sprawowania nadzoru właścicielskiego przez członków rodziny na wielkość nakładów na innowacje (ale nie stwierdzono negatywnego wpływu własności) w FR; stwierdzono także pozytywny wpływ zarządzania przez członków rodziny na wyniki innowacji (mierzone liczbą patentów i ich cytowalnością) oraz tylko częściowo potwierdzono w nich hipotezę o pozytywnym wpływie nadzoru właścicielskiego rodziny na wyniki innowacji.

Uzyskiwane niejednoznaczne wyniki badań dotyczące wpływu rodzinności na poziom innowacyjności przedsiębiorstw rodzinnych, a także ich wyniki powoduje, że szuka się czynników moderujących te relacje. $Z$ analizy literatury wynika, że badania na ten temat dotyczą w szczególności moderującej roli zaangażowania rodziny $w$ zarządzanie firmą w kształtowaniu relacji pomiędzy nakładami i wynikami innowacji (innovation inputs and output) technologicznych a dokonaniami tych przedsiębiorstw. Ponadto badania wskazują, że zaangażowanie rodziny w zarządzanie firmą negatywnie moderuje relacje pomiędzy nakładami na $B+R$ a ciągłymi innowacjami technologicznymi, ale może się zmieniać w czasie (Dieguez-Soto i in., 2016) oraz że zarządzanie przez członków rodziny pozytywnie moderuje związki pomiędzy wynikami innowacji technologicznych (innovation output) a ogólnymi wynikami firm, osiąganymi w długim okresie czasu (Diéguez-Soto i in., 2018).

Złożoność wpływu czynnika rodzinności (badanego w różnych ujęciach: głównie jako wpływ rodziny - family influence, mierzony zakresem własności) na różne obszary funkcjonowania przedsiębiorstw rodzinnych, $\mathrm{w}$ tym - jak można przypuszczać - także na poziom innowacyjności, skutkuje uwzględnieniem $\mathrm{w}$ badaniach także innych zmiennych moderujących, takich jak np.: wielkość czy wiek tych firm (Lwango i in., 2017). Badania, w których uwzględniono te zmienne moderujące, jak wielkość i wiek FR (Price i in., 2013), pokazują, że czynniki te mogą „rozluźniać" relacje pomiędzy firmą a rodziną, a więc osłabiać wpływ rodzinności.

Istniejący stan wiedzy wynikający $\mathrm{z}$ badań prowadzonych $\mathrm{w}$ różnych krajach wskazuje na dążenie FR do unikania ryzyka związanego $\mathrm{z}$ innowacjami (Chrisman i in., 2015), co może ograniczać zakres inwestowania $\mathrm{w}$ innowacje. FR zorientowane są nie tylko na realizację celów finansowych, ale duże znaczenie mają również cele pozaekonomiczne, co także może demotywować do inwestowania i rozwoju firmy poprzez innowacje. Ponadto czynnikiem ograniczającym inwestycje FR w działalność innowacyjną może być ich skala działania i wielkość - w Polsce zdecydowanie wśród tych firm dominują mikro- i małe przedsiębiorstwa. Jeśli zaś FR przeznaczają określone środki na działalność innowacyjną, to zaangażowanie rodziny we własny biznes powoduje maksymalne wykorzystanie tych nakładów, tak aby jednocześnie minimalizować ryzyko porażki i zapewnić poprawę wyników przedsiębiorstwa (Matzler i in., 2015). $\mathrm{Na}$ tej podstawie sformułowano następujące hipotezy dotyczące tych relacji:

Hipoteza 1: Rodzinność przedsiębiorstwa jest pozytywnie powiązana z nakładami ponoszonymi na innowacje.

Hipoteza 2: Rodzinność przedsiębiorstwa jest pozytywnie powiązana $\mathrm{z}$ wynikami aktywności innowacyjnej mierzonymi liczbą wdrożeń. 
Hipoteza 3. Nakłady ponoszone na innowacje są mediatorem $\mathrm{w}$ zależności pomiędzy rodzinnością przedsiębiorstwa a wynikami aktywności innowacyjnej mierzonymi liczbą wdrożeń.

Hipoteza 4: Wielkość i wiek przedsiębiorstw rodzinnych moderują relacje pomiędzy rodzinnością przedsiębiorstwa a poziomem innowacyjności.

\section{Metodyka prowadzonych badań empirycznych}

C elem weryfikacji sformułowanych wyżej zależności, w drugiej połowie 2017 r., przeprowadzono badania empiryczne na próbie 200 krajowych przedsiębiorstw rodzinnych. W szczególności z bazy małych i średnich przedsiębiorstw rodzinnych pracownicy Centrum Badań i Transferu Wiedzy przy UE w Katowicach wylosowali populację ponad 1000 przedsiębiorstw, z którymi kontaktowano się elektronicznie. Udział $\mathrm{w}$ badaniach zadeklarowało 213 przedsiębiorstw, przy czym kompletnych kwestionariuszy zebrano 200 i te włączone zostały do procesu analizy. Respondentami w badaniu byli właściciele lub wskazani przez nich menedżerowie badanych przedsiębiorstw rodzinnych, którzy otrzymywali link do ankiety pocztą elektroniczną, co było poprzedzone kontaktem telefonicznym. Narzędziem pomiaru był kwestionariusz badawczy, w którym zawarto pytania dotyczące między innymi nakładów na innowacje, poziomu innowacyjności oraz rodzinności. Charakterystykę próby przedstawiono w tabeli 1 .

Aby zmierzyć wyniki aktywności innowacyjnej, zastosowano zasady określone w podręczniku Oslo, biorąc pod uwagę liczbę wdrożonych rozwiązań innowacyjnych w ciągu ostatnich trzech lat. Ta decyzja podyktowana była faktem niskiego poziomu obejmowania ochroną patentową nowych produktów, procesów czy rozwiązań w Polsce. Nowatorskim rozwiązaniem na tym etapie było wzbogacenie oryginalnej koncepcji innowacyjności przedstawionej w raporcie Oslo Manual o innowacje zarządcze, które rozumiane były jako nowe metody i techniki zarządzania, a w szczególności planowania oraz implementacji nowych struktur organizacyjnych, a także systemów wynagradzania i kontroli. Do pomiaru nakładów na innowacyjność (innovation input) wykorzystano oszacowany przez respondentów procent przychodów ze sprzedaży przeznaczany na działalność innowacyjną w ciągu ostatnich trzech lat.
Do pomiaru rodzinności wybrano skalę Family Influence Familiness Scale (FIFS), stworzoną przez H. Franka i innych (2016). W oryginale skala ta składała się z 20 stwierdzeń ocenianych na 7-punktowej skali Likerta, a tworzy ją 6 wymiarów: własności, zarządzania i kontroli, doświadczenia aktywnych członków rodziny, dzielenia się informacją przez aktywnych członków rodziny, orientacji transpokoleniowej, więzi pomiędzy rodziną i pracownikami oraz tożsamości przedsiębiorstwa rodzinnego. Niemniej, mając na uwadze uprzednio przeprowadzone badania nad przedmiotowym zagadnieniem, skalę tę skrócono do 16 elementów tworzących 6 wymienionych wymiarów (por. wyniki analizy czynnikowej K. Bratnickiej-Myśliwiec, T. Ingrama, 2017). Współczynnik alfa Cronbacha dla tej skali wyniósł 0,932. Aby zapewnić rzetelność dalszych obliczeń prowadzonych celem weryfikacji hipotez i możliwości zastosowania techniki modelowania równań strukturalnych, dla 6 wskazanych wymiarów rodzinności obliczono metazmienne jako wartości średnie poszczególnych stwierdzeń wykorzystanych do pomiaru rodzinności, zgodnie z oryginalną koncepcją H. Franka i innych (2016).

\section{Wyniki badań empirycznych}

A by dokonać oceny zależności pomiędzy badanymi zmiennymi, w pierwszej kolejności posłużono się analizą korelacji liniowej Pearsona pomiędzy badanymi zmiennymi: wymiarami rodzinności (6 wymiarów). Tabela 2 przedstawia wyniki tej analizy wraz z podstawowymi statystykami opisowymi (średnia, odchylenie standardowe). Dla większej czytelności w tabeli 2 wytłuszczono związki istotne statystycznie. Analiza tabeli korelacji prowadzi do przynajmniej czterech wniosków. Po pierwsze, wszystkie wymiary rodzinności są negatywnie powiązane $\mathrm{z}$ wynikami aktywności innowacyjnej mierzonymi liczbą wdrożeń. Jednocześnie, wszystkie wymiary rodzinności (z wyjątkiem tożsamości przedsiębiorstwa rodzinnego) są pozytywnie powiązane $z$ nakładami na innowacje ponoszonymi przez przedsiębiorstwa rodzinne. Po drugie, istnieje silna, dodatnia zależność pomiędzy nakładami na innowacje a poziomem aktywności innowacyjnej (liczbą wdrożeń). Po trzecie, wymiary rodzinności są ze sobą relatywnie silnie skorelowane. W końcu wiek i wielkość przedsiębiorstwa rodzinnego mają związek z poziomem rodzinności i innowacyjnością badanych przedsiębiorstw, a w szczególności

Tabela 1. Charakterystyka próby badawczej

\begin{tabular}{|c|c|c|c|c|c|}
\hline \multicolumn{2}{|c|}{ Generacja właścicieli } & \multicolumn{2}{|c|}{ Własność rodziny } & \multicolumn{2}{c|}{ Wielkość przedsiębiorstwa } \\
\hline Pierwsza & 135 & $100 \%$ & 156 & Mikro (do 10 pracowników & 92 \\
\hline Druga & 49 & $50 \%$ i więcej & 44 & Małe & 84 \\
\hline Trzecia i kolejna & 16 & & & Średnie & 20 \\
\hline & & & & Duże & 4 \\
\hline RAZEM & 200 & RAZEM & 200 & RAZEM & 200 \\
\hline
\end{tabular}

Źródło: opracowanie wtasne 
wielkość przedsiębiorstwa powiązana jest dodatnio z liczbą wdrożonych innowacji, nakładami na innowacje i wiekiem przedsiębiorstwa, a negatywnie $\mathrm{z}$ wymiarami rodzinności. Natomiast wiek przedsiębiorstwa powiązany jest dodatnio z nakładami na innowacje i z wielkością przedsiębiorstwa.

W celu głębszego rozpoznania zależności pomiędzy rodzinnością a innowacyjnością przedsiębiorstw rodzinnych przeprowadzono modelowanie równań strukturalnych w programie Mplus 8.2 for Mac. Zmiennymi zależnymi $\mathrm{w}$ modelu były poziom innowacyjności przedsiębiorstwa mierzony liczbą wdrożeń oraz nakłady na innowacyjność. Zmienne kontrolne (oraz wykorzystane jako moderatory zależności pomiędzy zmienną niezależną a zmienną zależną) to wiek i wielkość przedsiębiorstwa. Kluczowa zmienna niezależna to rodzinność przedsiębiorstwa. W ocenie rodzinności przyjęto niestosowane dotychczas w odniesieniu do tego konstruktu rozstrzygnięcie metodologiczne, polegające na potraktowaniu go jako zmiennej reflektywnej dru- giego poziomu. Oznacza to, że rodzinność jest zjawiskiem utajonym, niepoddającym się pomiarowi bezpośrednio, lecz wpływającym na 6 wymiarów, z których każdy opisywany jest przez stwierdzenia odnoszące się do obserwowanych zjawisk (w odniesieniu do struktury czynnikowej - patrz fragment metodyczny). Zabieg ten jest stosowany w przypadku, gdy istnieje podstawa teoretyczna dla takiej specyfikacji konstruktu badawczego. W tym przypadku, mając na uwadze silne korelacje pomiędzy poszczególnymi wymiarami rodzinności (wahające się w przedziale $0,5-0,8$ ) (por. tab. 2), nie ma podstaw do odrzucenia założenia mówiącego, że rodzinność jest zmienną reflektywną, której odzwierciedleniem są jej poszczególne wymiary.

Oszacowano trzy modele, przy czym w pierwszym (1) oceniono wpływ zmiennych kontrolnych na dwie zmienne zależne (poziom innowacyjności i nakłady na innowacje), w drugim (2) do modelu włączono zmienną niezależną (rodzinność), w trzecim kroku (3) model

Tabela 2. Korelacje pomiędzy badanymi zmiennymi i statystyki opisowe

\begin{tabular}{|c|c|c|c|c|c|c|c|c|c|c|}
\hline & 1 & 2 & 3 & 4 & 5 & 6 & 7 & 8 & 9 & 10 \\
\hline $\begin{array}{l}\text { 1. Poziom aktywności } \\
\text { innowacyjnej }\end{array}$ & 1 & & & & & & & & & \\
\hline $\begin{array}{l}\text { 2. Nakłady na } \\
\text { innowacje }\end{array}$ & $0,172^{*}$ & 1 & & & & & & & & \\
\hline \multicolumn{11}{|c|}{ Wymiary rodzinności } \\
\hline $\begin{array}{l}\text { 3. Własność, } \\
\text { zarządzanie } \\
\text { i kontrola }\end{array}$ & $-0,402^{\star *}$ & $0,316^{\star *}$ & 1 & & & & & & & \\
\hline $\begin{array}{l}\text { 4. Orientacja } \\
\text { międzypokoleniowa }\end{array}$ & $-0,470^{* *}$ & $0,325^{\star *}$ & $0,817^{\star *}$ & 1 & & & & & & \\
\hline $\begin{array}{l}\text { 5. Dzielenie się } \\
\text { informacją przez } \\
\text { członków rodziny }\end{array}$ & $-0,473^{* *}$ & $0,283^{\star \star}$ & $0,745^{\star \star}$ & $0,830^{\star *}$ & 1 & & & & & \\
\hline $\begin{array}{l}\text { 6. Tożsamość } \\
\text { przedsiębiorstwa } \\
\text { rodzinnego }\end{array}$ & $-0,216^{* *}$ & 0,117 & $0,515^{\star *}$ & $0,596^{\star *}$ & $0,523^{\star *}$ & 1 & & & & \\
\hline $\begin{array}{l}\text { 7. Więzi między } \\
\text { rodziną } \\
\text { i pracownikami }\end{array}$ & $-0,424^{* *}$ & $0,216^{\star *}$ & $0,641^{\star *}$ & $0,638^{\star *}$ & $0,657^{\star *}$ & $0,587^{\star *}$ & 1 & & & \\
\hline $\begin{array}{l}\text { 8. Doświadczenie } \\
\text { aktywnych } \\
\text { członków rodziny }\end{array}$ & $-0,420^{* *}$ & $0,192^{\star *}$ & $0,656^{\star *}$ & $0,623^{\star *}$ & $0,681^{\star *}$ & $0,414^{\star *}$ & $0,563^{\star *}$ & 1 & & \\
\hline \multicolumn{11}{|c|}{ Zmienne kontrolne / moderator } \\
\hline $\begin{array}{l}\text { 9. Wielkość } \\
\text { przedsiębiorstwa }\end{array}$ & $0,154^{*}$ & $0,167^{*}$ & $-0,202^{\star *}$ & $-0,153^{\star}$ & $-0,145^{*}$ & $-0,113$ & $-0,165^{\star}$ & $-0,239^{* *}$ & 1 & \\
\hline $\begin{array}{l}\text { 10. Wiek } \\
\text { przedsiębiorstwa } \\
\text { w latach (ln wieku } \\
\text { przedsiębiorstwa) }\end{array}$ & $-0,28$ & $0,254^{\star \star}$ & 0,071 & 0,121 & 0,106 & 0,094 & 0,071 & 0,078 & $0,370^{* *}$ & 1 \\
\hline Średnia & 5,245 & 1,695 & 5,6038 & 5,7067 & 5,735 & 5,1167 & 5,6667 & 5,765 & 1,68 & 17,75 \\
\hline $\begin{array}{l}\text { Odchylenie } \\
\text { standardowe }\end{array}$ & 3,98804 & 0,71732 & 1,29147 & 1,22489 & 1,26998 & 1,04385 & 1,10225 & 1,6319 & 0,73505 & 15,86335 \\
\hline
\end{tabular}

$\mathrm{N}=200 ;{ }^{*}$ - korelacja istotna na poziomie $\mathrm{p}<0,05 ;{ }^{* *}$ - korelacja istotna na poziomie $\mathrm{p}<0,01$

Źródto: opracowanie wtasne 
wzbogacono o analizę mediacji i moderacji (jako mediator w zależności pomiędzy rodzinnością a poziomem innowacyjności przyjęto nakłady na innowacje, zaś wiek i wielkość przedsiębiorstwa to moderatory podstawowej zależności określonej $\mathrm{w}$ hipotezie 2). Wyniki estymacji modeli wraz z parametrami ich oszacowania i błędami standardowymi prezentuje tabela 3 .

W pierwszym modelu stopień wyjaśniania wyników aktywności innowacyjnej (innovation output) wynosi zaledwie 3,2\% i jest nieistotny statystycznie. Spośród dwóch zmiennych kontrolnych wielkość przedsiębiorstwa jest istotną determinantą aktywności innowacyjnej (im większe przedsiębiorstwo, tym większa liczba nowatorskich rozwiązań), natomiast nakłady na innowacje są wyjaśniane przez wiek przedsiębiorstwa, przy czym im starsze przedsiębiorstwo, tym większą część swoich przychodów ze sprzedaży przeznacza na innowacje. W modelu tym nie podano parametrów oszacowania, gdyż przy 4 zmiennych obserwowanych i relatywnie dużej liczbie obserwacji są one zbliżone do wartości idealnych (model oszacowany

Tabela 3. Zależności pomiędzy rodzinnością a wynikami firm rodzinnych

\begin{tabular}{|c|c|c|c|}
\hline Model & Model 1 & Model 2 & Model 3 \\
\hline & $\begin{array}{c}\text { Model bazowy: } \\
\text { innowacyjność I nakłady na } \\
\text { innowacje w kontekście wieku } \\
\text { I wielkości przedsiębiorstwa }\end{array}$ & $\begin{array}{c}\text { Zależności pomiędzy } \\
\text { rodzinnością a nakładami } \\
\text { na innowacje i poziomem } \\
\text { innowacyjności } \\
\text { przedsiębiorstwa rodzinnego }\end{array}$ & $\begin{array}{c}\text { Zależności pomiędzy } \\
\text { rodzinnością a poziomem } \\
\text { innowacyjności przedsiębiorstwa } \\
\text { rodzinnego: moderująca } \\
\text { rola wieku i wielkości } \\
\text { przedsiębiorstwa rodzinnego } \\
\text { i mediująca rola nakładów na } \\
\text { innowacje }\end{array}$ \\
\hline \multicolumn{4}{|c|}{ Statystyki dopasowania modeli } \\
\hline RMSEA & - & 0,053 & $\mathrm{n} / \mathrm{a}^{*}$ \\
\hline CFI (Compound Fit Index) & - & 0,984 & $\mathrm{n} / \mathrm{a}^{*}$ \\
\hline TLI (Tucker-Lewis Index) & - & 0,975 & $\mathrm{n} / \mathrm{a}^{*}$ \\
\hline Akaike information criteria & - & 4558,817 & 4562,374 \\
\hline \multirow[t]{2}{*}{ r2 (dla wyników aktywności innowacyjnej) } & $0,032(0,024)$ & $0,260(0,000)$ & $0,392(0,000)$ \\
\hline & Parametr modelu (p-value) & Parametr modelu (p-value) & Parametr modelu (p-value) \\
\hline \multicolumn{4}{|c|}{ Wyniki aktywności innowacyjnej jako zmienna zależna } \\
\hline Wiek przedsiębiorstwa & $-0,473(0,191)$ & $0,048(0,882)$ & $-0,210(0,497)$ \\
\hline Wielkość przedsiębiorstwa & $1,030(0,011)$ & $0,289(0,431)$ & $-0,116(0,736)$ \\
\hline $\begin{array}{l}\text { Rodzinność przedsiębiorstwa rodzinnego } \\
\text { (zmienna utajona) }\end{array}$ & - & $-1,824(0,000)$ & $-1,839(0,012)$ \\
\hline Nakłady na innowacje & - & - & $2,193(0,000)$ \\
\hline \multicolumn{4}{|c|}{ Nakłady na innowacje jako zmienna zależna } \\
\hline Wiek przedsiębiorstwa & $0,194(0,002)$ & $0,131(0,032)$ & $0,131(0,032)$ \\
\hline Wielkość przedsiębiorstwa & $0,082(0,252)$ & $0,171(0,014)$ & $0,171(0,014)$ \\
\hline $\begin{array}{l}\text { Rodzinność przedsiębiorstwa rodzinnego } \\
\text { (zmienna utajona) }\end{array}$ & - & $0,220(0,000)$ & $0,220(0,000)$ \\
\hline \multicolumn{4}{|c|}{$\begin{array}{l}\text { Mediująca rola nakładów na innowacje w zależności pomiędzy rodzinnością } \\
\text { a wynikami aktywności innowacyjnej (efekty pośrednie) }\end{array}$} \\
\hline Mediator: nakłady na innowacje & - & - & $0,482(0,000)$ \\
\hline \multicolumn{4}{|c|}{$\begin{array}{l}\text { Moderująca rola wieku i wielkości przedsiębiorstwa w zależności pomiędzy rodzinnością a wynikami } \\
\text { aktywności innowacyjnej (Parametry interakcji pomiędzy moderatorem a zmienną niezależną) }\end{array}$} \\
\hline $\begin{array}{l}\text { Moderator: wielkość przedsiębiorstwa } \\
\text { rodzinnego }\end{array}$ & - & - & $-0,055(0,870)$ \\
\hline $\begin{array}{l}\text { Moderator: wiek przedsiębiorstwa } \\
\text { rodzinnego }\end{array}$ & - & - & $-0,153(0,648)$ \\
\hline
\end{tabular}

Parametry modelu istotne statystycznie zostały wytłuszczone

* - ze względu na losowy typ analizy w mplus (type:random) nie ma możliwości podania wspótczynnika dopasowania 
jest zgodny $\mathrm{z}$ hipotetycznym). Model ten stanowi jedynie punkt odniesienia dla modeli 2 i 3 .

W modelu 2 istotnie wzrasta poziom wyjaśniania wyników aktywności innowacyjnej i wynosi 26\% (i jest istotny statystycznie). W modelu tym zmienność wyników aktywności innowacyjnej może być przypisana przede wszystkim poziomowi rodzinności. W szczególności, im wyższy poziom rodzinności, tym niższy poziom wyników aktywności innowacyjnej. Wyniki analizy niosą zatem wsparcie dla hipotezy H2, gdyż rodzinność jest istotnym predyktorem innowacyjności przedsiębiorstwa. Natomiast nakłady na innowacje są wyjaśniane przez dwie zmienne kontrolne (wiek i wielkość; im starsze i większe przedsiębiorstwo, tym więcej przychodów ze sprzedaży przeznacza na działalność innowacyjną) oraz przez rodzinność - im wyższy poziom rodzinności przedsiębiorstwa, tym wyższy poziom nakładów na innowacje. Niesie to wsparcie dla hipotezy $\mathrm{H} 1$ i potwierdza założenie, że rodzinność jest powiązana $\mathrm{z}$ nakładami na innowacyjność. Model ten jest oszacowany na w pełni zadowalającym poziomie, przy RMSEA < 0,06, a CFI i TLI > od 0,9 . Kryterium informacyjne Akaike przyjmuje wartość 4558,8 , przy czym wartość ta sama w sobie służy jedynie do porównywania dwóch lub więcej modeli i nie poddaje się interpretacji (została podana, aby porównać modele 2 i 3, gdyż w modelu 3, ze względu na procedurę testów moderacji w modelach SEM nie ma możliwości podania statystyk dopasowania modeli: RMSEA, CFI i TLI).

Model 3 wyjaśnia największą część wariancji zmiennej zależnej $\left(\mathrm{r}^{2}=39,2 \%\right)$. Wyniki estymacji tego modelu wskazują, że rodzinność jest istotną determinantą zarówno wyników aktywności innowacyjnej, jak i nakładów na innowacje. Jednocześnie analiza mediacji wskazuje, że nakłady na innowacje są mechanizmem obniżającym negatywny wpływ rodzinności na wyniki działalności innowacyjnej. Mediacja ta ma charakter częściowy, gdyż obok wpływu pośredniego, istotnego statystycznie $(0,482$; $\mathrm{p}=0,000$ ), istotny pozostaje także wpływ bezpośredni $(-1,839 ; \mathrm{p}=0,012)$. Przynosi to częściowe potwierdzenie hipotezy H3, głoszącej o mediującym wpływie wydatków na innowacje $\mathrm{w}$ zależności pomiędzy rodzinnością a poziomem aktywności innowacyjnej. Wyniki nie dają natomiast podstaw do przyjęcia hipotezy H4, gdyż ani wiek, ani wielkość przedsiębiorstwa nie odgrywają istotnej roli w moderowaniu głównej badanej zależności pomiędzy rodzinnością a poziomem aktywności innowacyjnej przedsiębiorstwa rodzinnego. Parametry $\beta$ przy efektach moderacji są niewielkie i nieistotne statystycznie.

\section{Dyskusja wyników badań}

A naliza wyników przeprowadzonych badań empirycznych doprowadziła do pozytywnej weryfikacji hipotezy 1 (rodzinność jest powiązana $\mathrm{z}$ nakładami ponoszonym na innowacje). Wyniki te nie pokrywają się z wynikami badań np.: P. Durana i innych (2016) czy K. Matzlera i innych (2015), przy czy w tym drugim przypadku nie wszystkie wymiary rodzinności wpływały w ten sam sposób na innowacje. Jednocześnie należy nadmie- nić, że im starsze i większe przedsiębiorstwa, tym więcej przychodów ze sprzedaży przeznaczają na działalność innowacyjną. W tym zakresie można przypuszczać, że wysoki poziom rodzinności w firmie oraz postępująca wraz z rozwojem firmy profesjonalizacja procesów zarządczych może wpływać pozytywnie na podejmowanie decyzji związanych z nakładami ponoszonymi na innowacje. Dodatkowo może to być powiązane $\mathrm{z}$ ugruntowaną pozycją rynkową firmy bądź też presją otoczenia na konieczność podejmowania działań o charakterze innowacyjnym oraz na akceptację ponoszonego $\mathrm{w}$ ten sposób ryzyka gospodarczego. W przypadku hipotezy 2 potwierdzono związek pomiędzy wymiarami rodzinności a wynikami aktywności innowacyjnej mierzonymi liczbą wdrożeń, ale wpływ ten jest negatywny, co również nie jest zgodne $\mathrm{z}$ wynikami zespołów badawczych przytoczonymi wyżej (Duran i in., 2016, s. 1224; Matzler i in., 2015).

Uzyskane wyniki wskazują, że w przedsiębiorstwach rodzinnych mniejsza, niż w podmiotach nierodzinnych, liczba pomysłów jest komercjalizowana. Przy jednoczesnej skłonności do wydawania większych kwot na procesy innowacyjne (innovation input) może to oznaczać, że pomysły są bardziej dokładnie testowane i na wstępnym etapie odrzucany jest znaczący procent nowych rozwiązań. Jednocześnie rodzinność tworzy w pewien sposób klimat sprzyjający realizacji działań innowacyjnych, które przecież nie zawsze muszą zakończyć się sukcesem w postaci kompleksowego wdrożenia pomysłu innowacyjnego. Dodatkowo należy zauważyć, że pozytywna weryfikacja hipotezy 1 jest zbieżna $\mathrm{z}$ wynikami badań prowadzonych przez J. Llacha i M. Nordqvista (2010).

Natomiast hipoteza 3 (nakłady ponoszone na innowacje są mediatorem w zależności pomiędzy rodzinnością a wynikami aktywności innowacyjnej mierzonymi liczbą wdrożeń) została zweryfikowana częściowo pozytywnie. Badania wskazujące na mediującą rolę nakładów ponoszonych na innowacje $\mathrm{w}$ badanej relacji raczej nie występują do tej pory w literaturze i trudno w tym zakresie znaleźć punkt odniesienia do interpretacji uzyskanych wyników przeprowadzonych badań empirycznych. Może to $\mathrm{w}$ pewnym zakresie stanowić wskazówkę dla zarządzających firmami rodzinnymi, że ponoszenie jedynie nakładów finansowych na innowacje nie jest kluczowym czynnikiem sukcesu w badanym obszarze innowacyjności organizacyjnej. Przyczyn innowacyjności przedsiębiorstw rodzinnych poszukiwać należy zatem nie tylko w rodzinności i nakładach na innowacyjność, ale również w innych obszarach determinujących liczbę innowacji: skłonności do uczenia się, nastawieniu umysłu na paradoks czy koncepcji bogactwa społeczno-emocjonalnego (Naldi i in., 2013), które są charakterystyczne dla przedsiębiorstw rodzinnych.

Z kolei hipoteza 4 (wielkość i wiek przedsiębiorstw rodzinnych moderują relacje pomiędzy rodzinnością a poziomem innowacyjności) została zweryfikowana negatywnie. Uzyskane wyniki nie pokrywają się z innymi wynikami badań, które uwzględniały zmienne moderujące w postaci wielkości i wieku FR (Price i in., 2013). Wielkość i wiek przedsiębiorstw nie wzmacniają zależności 
pomiędzy rodzinnością a poziomem innowacyjności. Może to wskazywać na fakt, iż wpływ rodzinności na poziom innowacyjności występuje $\mathrm{w}$ różnych kontekstach organizacyjnych. Jednocześnie warto podkreślić, że przeprowadzone badania potwierdzają dodatnią korelację pomiędzy zarówno wielkością firm rodzinnych, jak i ich okresem istnienia a nakładami na innowacje oraz dodatnią zależność pomiędzy wielkością firm a liczbą wdrażanych innowacji.

Najważniejsze ograniczenia dotyczą przyjętego podejścia metodycznego i są trojakie. Po pierwsze, pomimo starań dotyczących zapewnienia reprezentatywności próby badawczej jej wielkość wymusza uproszczenia analityczne na etapie konstrukcji i estymacji modeli równań strukturalnych wykorzystanych do weryfikacji hipotez. Było to powodem niewłączenia do analizy szeregu zmiennych mediujących i moderujących (np. bogactwa społeczno-emocjonalnego czy strategii innowacji przez tradycję, charakterystycznych dla przedsiębiorstw rodzinnych - Bratnicka-Myśliwiec, Ingram, 2017), które mogłyby dopomóc w lepszym zrozumieniu wpływu rodzinności na innowacyjność przedsiębiorstwa - stanowi to w przekonaniu autorów drugie istotne ograniczenie badań. Po trzecie, dane dotyczące rodzinności i innowacyjności gromadzone były w każdym przedsiębiorstwie z wyłącznie jednego źródła, co może przyczyniać się do powstania systematycznego błędu pomiaru i obciąża wyniki prowadzonych analiz (Certo i in., 2016, s. 2639).

\section{Podsumowanie}

$\mathbf{Z}$ aprezentowane wyniki badań empirycznych przeprowadzonych na próbie polskich FR mogą być kolejnym dowodem na wielką złożoność powiązań pomiędzy rodzinnością a innowacjami, która implikuje liczne kontrowersje wokół tego tematu. Wyniki badań wskazują na różnice $\mathrm{w}$ zachowaniach innowacyjnych polskich FR w porównaniu z FR w innych krajach, co może być skutkiem wielu różnic pomiędzy warunkami, w jakich funkcjonują. Zidentyfikowane relacje pomiędzy badanymi zmiennymi $\mathrm{w}$ polskich FR są pod wpływem odmiennego kontekstu politycznego, ekonomicznego, społecznego czy rozwiązań prawnych, a także innych czynników, które kształtują zachowania innowacyjne FR i jednocześnie różnicują je. Można przypuszczać, że kontekst ten, zwłaszcza krótki okres funkcjonowania gospodarki rynkowej w krajach posttransfomacyjnych, takich jak Polska, relatywnie krótka tradycja przedsiębiorczości rodzinnej oraz niższy poziom życia w Polsce (w porównaniu z krajami „starej” UE) może implikować istotne różnice w funkcjonowaniu FR w Polsce. $\mathrm{W}$ przyszłych badaniach $\mathrm{z}$ pewnością należy uwzględnić m.in. szeroko rozumiane uwarunkowania funkcjonowania FR, motywacje do podejmowania decyzji o inwestowaniu w działalność innowacyjną, o rodzajach wdrażanych innowacji (inkrementalne czy radykalne). Należy również pamiętać, że w prowadzonych badaniach przedsiębiorczości rodzinnej przyjmowane są różne podejścia do definiowania rodzinności i sposobów jej pomiaru (podobnie zresztą jak w przypadku pomiaru innowacyjności).
Próbując odpowiedzieć na postawione w tytule artykułu pytanie: czy rodzinność polskich przedsiębiorstw rodzinnych jest stymulatorem czy przeszkodą innowacyjności, na podstawie analizy wyników przeprowadzonych badań empirycznych (bazujących na przeglądzie literatury przedmiotu oraz prowadzonych dotychczas badaniach w tym zakresie), można skłonić się ku odpowiedzi pozytywnej. Rodzinność, rozumiana jako unikalna wiązka zasobów odzwierciedlająca stopień zintegrowania rodziny, przedsiębiorstwa i zarządzania może stanowić istotny czynnik determinujący innowacyjność przedsiębiorstwa rodzinnego. Wskazuje to na konieczność dalszej eksploracji tego zjawiska, $\mathrm{z}$ uwzględnieniem m.in. czynnikw kontekstualnych nie będcych przedmiotem tych badań.

\section{dr hab. Teresa Kraśnicka, prof. uczelni Uniwersytet Ekonomiczny w Katowicach Wydział Ekonomii \\ ORCID: 0000-0002-6862-2901 \\ e-mail: teresa.krasnicka@ue.katowice.pl}

\author{
dr hab. Tomasz Ingram, prof. uczelni \\ Uniwersytet Ekonomiczny w Katowicach \\ Wydział Ekonomii \\ ORCID: 0000-0002-4161-6261 \\ e-mail: tomasz.ingram@ue.katowice.pl
}

\section{dr hab. Grzegorz Głód, prof. uczelni Uniwersytet Ekonomiczny w Katowicach Wydział Ekonomii \\ ORCID: 0000-0001-9699-2427 \\ e-mail: grzegorz.glod@ue.katowice.pl}

\section{Bibliografia}

[1] Arzubiaga U., Kotlar J., De Massis A., Maseda A., Iturralde T. (2018), Entrepreneurial Orientation and Innovation in Family SMEs: Unveiling the (Actual) Impact of the Board of Directors, „Journal of Business Venturing”, Vol. 33, No. 4, pp. 455-469.

[2] Bratnicka-Myśliwiec K., Ingram T. (2017), Rodzinność i przewaga konkurencyjna. Kontekst polskich przedsiębiorstw, „Edukacja Ekonomistów i Menedżerów”, Nr 43, s. 135-153.

[3] Carnes C.M., Ireland R.D. (2013), Familiness and Innovation: Resource Bundling as the Missing Link, „Entrepreneurship Theory and Practice", Vol. 37, No. 6, pp. 1399-1419.

[4] Certo S.T., Busenbark J.R., Woo H.S., Semadeni M. (2016), Sample Selection Bias and Heckman Models in Strategic Management Research, „Strategic Management Journal”, Vol. 37, No. 13, pp. 2639-2657.

[5] Chrisman J.J., Chua J.H., Litz R. (2003), A Unified Systems Perspective of Family Firm Performance: An Extension and Integration, „Journal of Business Venturing", Vol. 18, No. 4, pp. 467-472.

[6] Chrisman J.J., Chua J.H., De Massis A., Frattini F., Wright M. (2015), The Ability and Willingness Paradox in Family Firm Innovation, „Journal of Product Innovation Management", Vol. 32, No. 3, pp. 310-318. 
[7] Chua J.H., Chrisman J.J., Steier L.P., Rau S.B. (2012), Sources of Heterogeneity in Family Firms: An Introduction, „Entrepreneurship Theory and Practice”, Vol. 36, No. 6, pp. 1103-1113.

[8] Classen N., Carree M., Van Gils A., Peters B. (2014), Innovation in Family and Non-family SMEs: An Exploratory Analysis, „Small Business Economics”, Vol. 42, No. 3, pp. 595-609.

[9] Crossan M.M., Apaydin M. (2010), A Multi - dimensional Framework of Organizational Innovation: A Systematic Review of the Literature, „Journal of Management Studies”, Vol. 47, No. 6, pp. 1154-1191.

[10] Daspit J.J., Chrisman J.J., Sharma P., Pearson A.W., Long R.G. (2017), A Strategic Management Perspective of the Family Firm: Past Trends, New Insights, and Future Directions, „Journal of Managerial Issues", Vol. 29, No. 1, pp. 6-29.

[11] Dawson A., Mussolino D. (2014) Exploring what Makes Family Firms Different: Discrete or Overlapping Constructs in the Literature? „Journal of Family Business Strategy”, Vol. 5, No. 2, pp. 169-183.

[12] De Massis A., Di Minin A., Frattini F. (2015), Family-driven Innovation: Resolving the Paradox in Family Firms, „California Management Review", Vol. 58, No. 1, pp. 5-19.

[13] Diéguez-Soto J., Garrido-Moreno A., Manzaneque M. (2018), Unravelling the Link between Process Innovation Inputs and Outputs: The Moderating Role of Family Management, „Journal of Family Business Strategy”, Vol. 9, No. 2, pp. 114-127.

[14] Diéguez-Soto J., Manzaneque M., Rojo-Ramírez A.A. (2016), Technological Innovation Inputs, Outputs, and Performance: The Moderating Role of Family Involvement in Management, „Family Business Review”, Vol. 29, No. 3, pp. 327-346.

[15] Duran P., Kammerlander N., Van Essen M., Zellweger T. (2016), Doing More with Less: Innovation Input and Output in Family Firms, „Academy of Management Journal”, Vol. 59, No. 4, pp. 1224-1264.

[16] Frank H., Kessler A., Rusch T., Suess-Reyes J., Weismeier-Sammer D. (2016), Capturing the Famiiliness of Family Business: Development of the Family Influence Familiness Scale (FIFS), „Entrepreneurship Theory and Practice”, Vol. 3, pp. 1-34.

[17] Fuetsch E., Suess-Reyes J. (2017), Research on Innovation in Family Businesses: Are We Building an Ivory Tower? „Journal of Family Business Management”, Vol. 7, No. 1, pp. 44-92.

[18] Habbershon T.G., Williams M.L. (1999), A Resource-based Framework for Assessing the Strategic Advantages of Family Firms, „Family Business Review”, Vol. 12, No. 1, pp. 1-25.

[19] Jaskiewicz P., Block J.H., Combs J.G., Miller D. (2017), The Effects of Founder and Family Ownership on Hired CEOs' Incentives and Firm Performance, „Entrepreneurship Theory and Practice”, Vol. 41, No. 1, pp. 73-103.

[20] Jeżak J. (2016), Rozwój przedsiębiorczości rodzinnej w Polsce na tle tendencji światowych, „Przegląd Organizacji”, Nr 4, s. 52-59.

[21] Kammerlander N., Dessi C., Bird M., Floris M., Murru A. (2015), The Impact of Shared Stories on Family Firm Innovation: A Multicase Study, „Family Business Review”, Vol. 28, No. 4, pp. 332-354.
[22] Kraśnicka T., Głód W., Wronka-Pośpiech M. (2016), Management Innovation and its Measurement, „Journal of Entrepreneurship, Management and Innovation", Vol. 12, No. 2, pp. 95-122.

[23] Kraśnicka T., Głód G. (2018), Związki pomiędzy innowacyjnościq a wynikami firm rodzinnych, „Przedsiębiorczość i Zarządzanie", Nr 19, 309-323.

[24] Kraśnicka T., Ingram T., Bratnicka K. (2016), Stan i kierunki dalszych badań nad zjawiskiem przedsiębiorczości rodzinnej w Polsce, Zeszyty Naukowe Politechniki Śląskiej, seria Organizacja i Zarządzanie, Nr 93, s. 285-297.

[25] Llach J., Nordqvist M. (2010), Innovation in Family and Non-family Businesses: A Resource Perspective, „International Journal of Entrepreneurial Venturing", Vol. 2, No. 3-4, pp. 381-399.

[26] Lwango A., Coeurderoy R., Giménez Roche G.A. (2017), Family Influence and SME Performance Under Conditions of Firm Size and Age, „Journal of Small Business and Enterprise Development", Vol. 24, No. 3, pp. 629-648.

[27] Mączyńska M. (2016), Firmy rodzinne. Nowo odkryta sita polskiej gospodarki, [w:] A. Tarnawa, A. Skowrońska (red.), Raport o stanie sektora malych i średnich przedsiębiorstw w Polsce, Polska Agencja Rozwoju Przedsiębiorczości, Warszawa.

[28] Matzler K., Veider V., Hautz J., Stadler Ch. (2015), The Impact of Family Ownership, Management, and Governance on Innovation, „Journal of Product Innovation Management", Vol. 32, No. 3, pp. 319-333.

[29] Muñoz-Bullón F., Sanchez-Bueno M.J. (2011), The Impact of Family Involvement on the ReD Intensity of Publicly Traded Firms, „Family Business Review”, Vol. 24, No. 1, pp. 62-70.

[30] Naldi L., Cennamo C., Corbetta G., Gomez-Mejia L. (2013), Preserving Socioemotional Wealth in Family Firms: Asset or Liability? The Moderating Role of Business Context, „Entrepreneurship Theory and Practice", Vol. 37, No. 6, pp. 1341-1360.

[31] Oslo Manual (2005), The Measurement of Scientific and Technological Activities. Proposed Guidelines for Collecting an Interpreting Technological Innovation Data.

[32] Poznańska K. (red.), (2018), Nowe formy innowacji, Oficyna Wydawnicza SGH, Warszawa.

[33] Price D.P., Stoica M., Boncella R.J. (2013), The Relationship between Innovation, Knowledge, and Performance in Family and Non-family Firms: An Analysis of SMEs, „Journal of Innovation and Entrepreneurship", Vol. 2, No. 1, 14-24.

[34] Sharma P. (2008), Commentary: Familiness: Capital Stocks and Flows between Family and Business, „Entrepreneurship Theory and Practice”, Vol. 11, pp. 971-977.

[35] Sharma P., Chrisman J.J., Gersick K.E. (2012), 25 Years of Family Business Review: Reflections on the Past and Perspectives for the Future, „Family Business Review”, Vol. 25, No. 1, pp. 5-15.

[36] Steeger J.H., Hoffmann M. (2016), Innovation and Family Firms: Ability and Willingness and German SMEs, „Journal of Family Business Management”, Vol. 6, No. 3, pp. 251-269.

[37] Steinerowska-Streb I. (2015), Bariery finansowe $w$ działalności polskich przedsiębiorstw rodzinnych, „Przedsiębiorczość i Zarządzanie", Vol. 16, pp. 351-369.

[38] Tokarczyk J., Hansen E., Green M., Down J. (2007), A Resource-based View and Market Orientation Theory Examination 
of the Role of „Familiness” in Family Business Success, „Family Business Review", Vol. 20, No. 1, pp. 17-31.

[39] Von Schlippe A., Frank H. (2013), The Theory of Social Systems as a Framework for Understanding Family Businesses, „Family Relations”, Vol. 62, No. 3, pp. 384-398.

[40] Weismeier-Sammer D., Frank H., von Schlippe A. (2013), Untangling 'Familiness' A Literature Review and Directions for Future Research, „The International Journal of Entrepreneurship and Innovation", Vol. 14, No. 3, pp. 165-177.

[41] Zellweger T.M., Eddleston K.A., Kellermanns F.W. (2010) Exploring the Concept of Familiness: Introducing Family Firm Identity, „Journal of Family Business Strategy", Vol. 1, No. 1, pp. 54-63.

\section{Familiness of Polish Family Enterprises - Innovation Stimulator or an Obstacle?}

\section{Summary}

For many years, family enterprises have been a research area in management science, and their characteristics are consistently subjected to a variety of theoretical and practical inquiries. Family life, understood as a unique bundle of resources reflecting the degree of integration of the family, enterprise and management, is a significant distinguishing feature of family enterprises. Bearing in mind the relatively low level of innovativeness of domestic enterprises, the main goal was formulated, which is the answer to the question about family relationships and the level of innovation of family businesses. In order to implement such a research project, in 2017 empirical research was carried out on a sample of 200 domestic family enterprises. The analyses have shown that familiness is linked to expenditures on innovation and the results of innovation activity measured by the number of implementations.

\section{Keywords}

innovation, family entrepreneurship, family business, familiness 